\title{
Fellhanera gyrophorica, a new European species with conspicuous pycnidia
}

\section{E. SÉRUSIAUX, B. J. COPPINS, P. DIEDERICH and C. SCHEIDEGGER}

\begin{abstract}
Fellhanera gyrophorica Sérus., Coppins, Diederich \& Scheidegger is described as new from Europe (Austria, Lithuania, Luxembourg, Poland, Switzerland and Ukraine). It is a sterile corticolous species with conspicuous and sometimes shortly stalked pycnidia whose outer walls produce gyrophoric acid. Its position in the genus Fellhanera (Pilocarpaceae) is tentative and further studies may necessitate its transfer to another genus.

C 2001 The British Lichen Society
\end{abstract}

\section{Introduction}

The genus Fellhanera Vězda is widely distributed in tropical, subtropical and temperate areas, with many foliicolous species. According to recent generic delimitations within the Pilocarpaceae, it is the most inclusive genus and forms the basis of the family as it supposedly exhibits most of the plesiomorphic character states (Lücking 1997; Lücking et al. 2001). The family so far includes the genera Badimia Vèzda, Bapalmuia Sérus., Byssoloma Trevis., Byssolecania Vain., Fellhanera Vězda and Fellhaneropsis Sérus. \& Coppins, but further genera should be distinguished in the forthcoming years (Kalb et al. 2000).

Details of the species included in the genus can be found in Vèzda (1986), Lücking et al. (1994), Sérusiaux (1996), Lücking (1997) and Lücking et al. (2001).

E. Sérusiaux: Research Associate F.N.R.S., Botany Dept, University of Liège, Sart Tilman B22, B-4000 Liège, Belgium.

B. J. Coppins: Royal Botanic Garden, Edinburgh EH3 5LR, U.K.

P. Diederich: Musée national d'histoire naturelle, rue Munster 25, L-2160 Luxembourg, G. D. Luxembourg. C. Scheidegger: Swiss Federal Institute for Forest, Snow and Landscape Research, WSL, CH-8903 Birmensdorf, Switzerland.
The continental European lichen flora includes the widespread and well-known Fellhanera bouteillei (Desm.) Vězda and $F$. subtilis (Vèzda) Diederich \& Sérus. Fellhanera christiansenii Sérus. \& Vězda is restricted to Italy (Calabria) where it is quite rare (Puntillo et al. 2000). The recently described $F$. viridisorediata Aptroot et al. is known from Austria, Belgium, Germany, Wales, S Sweden and The Netherlands (Aptroot et al. 1998; Ekman \& Arup 2000; Orange 1999; Spier \& Aptroot 2000) while F. ochracea Sparrius \& Aptroot has been found in Great Britain, The Netherlands and Switzerland (Sparrius \& Aptroot 2000). A key to the species of W Europe is provided by Sparrius \& Aptroot (2000). A further new species is described in this paper.

\section{The Species}

\section{Fellhanera gyrophorica Sérus., Coppins, Diederich \& Scheidegger} sp. nov.

=Fellhanera sp. 1 in Diederich, P., Trav. Sci. Mus. nat. hist. nat. Luxemb. 14: 102 (1989).

=Fellhanera sp. in Scheidegger, C. et al., Mitt. Aargau. Naturf. Ges. 33: 179 (1991).

=Fellhanera sp. in Diederich, P. \& Sérusiaux, E., The Lichens and Lichenicolous Fungi of Belgium and Luxembourg. An Annotated Checklist. Musée national d'histoire naturelle, Luxembourg: 101, (2000). 


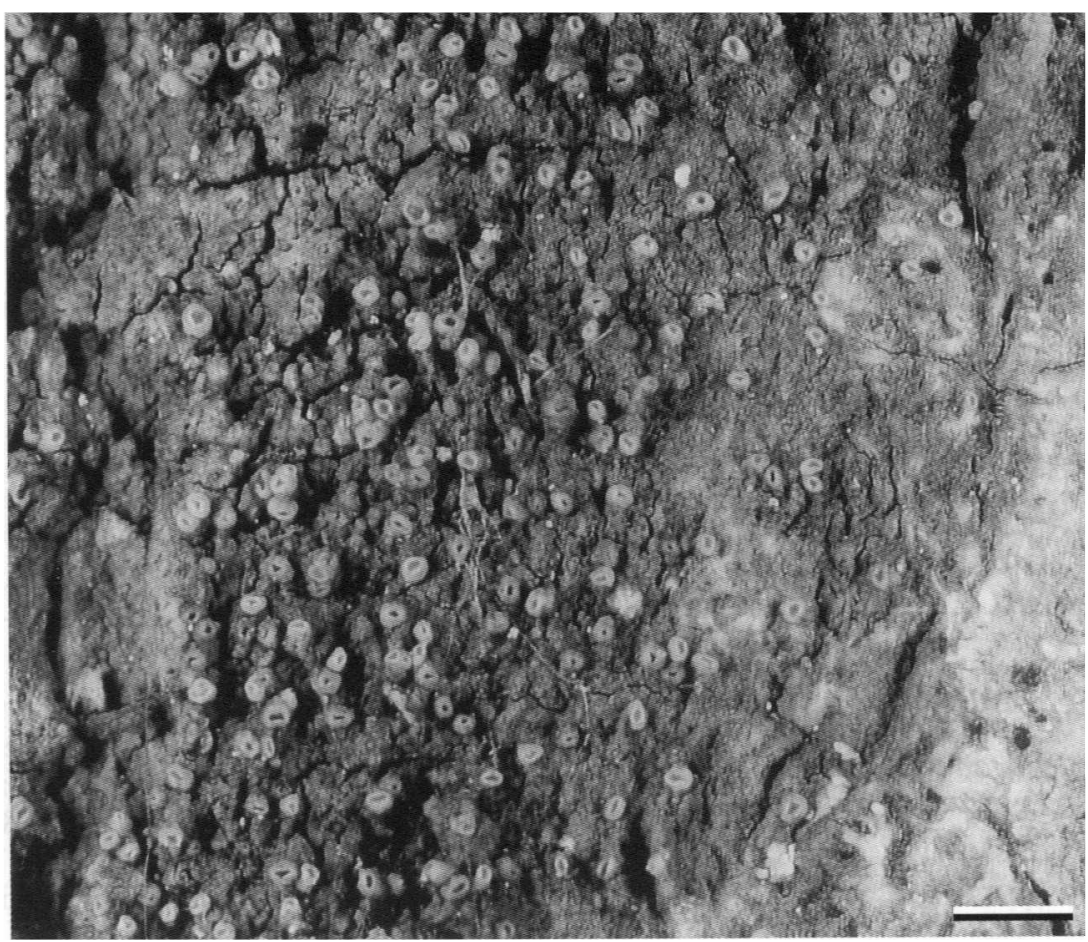

FIG. 1. Thallus and pycnidia of Fellhanera gyrophorica on bark of Carpinus (photograph taken in the field by C. Scheidegger in Ukraine, Zhornava, $27 \mathrm{v} 1998$ ). Scale $=1 \mathrm{~mm}$.

Species corticola semper sterilis, pycnidiis conspicuis, sessilibus vel breviter stipitatis (stipite usque ad $30 \mu \mathrm{m}$ longo), paricte externo $\mathrm{C}+$ rubro reagenti (acidum gyrophoricum continenti); conidia obpyriformia, raro ellipsoidea vel biclavata, $3-3.5 \times 1-1.5 \mu \mathrm{m}$.

Typus: Austria, Steiermark, Oststeirisches Hügelland, Bezirk Feldbach, Gleichenberger Kogel, Steinbruch W des Kogels und nördliche Abhänge, $380 \mathrm{~m}, 19$ March 1993, auf Borke von Aluts glutinosa, B. Wieser 1987 (GZU-holotype).

(Fig. 1)

Thallus corticolous, or invading corticolous mosses and liverworts, forming large and conspicuous patches up to $2-3 \mathrm{~cm}$ across, or streaks along the bark fissures up to $5-6 \mathrm{~cm}$ long, or dispersed and hardly seen amongst other crustose species or bryophytes and then quite indistinct, pale yellowish green to green, sometimes with a slight bluish tinge, made up of scattered to densely aggregated goniocysts and thus finely farinose or scurfy granular, rather thin or much thicker when well-developed and then granular-warted, rarely with a felt-like appearance, never smooth nor isidioid; margin ill-defined, without prothallus. Photobiont most probably a species of Chlorococcaceae, with green, spherical cells, 6-10(-12) $\mu \mathrm{m}$ diam.

Pycnidia always present, sessile or slightly stalked, sometimes aggregated in clusters, pinkish to pale orange-brown, with their outer wall slightly pruinose when welldeveloped and typically reacting $\mathrm{C}+\mathrm{red}$ because of production of gyrophoric acid (checked by TLC for several specimens, incl. the type), $0 \cdot 1-0 \cdot 25 \mathrm{~mm}$ diam., and up to $0 \cdot 1-0 \cdot 2(-0.3) \mathrm{mm}$ high; stalk indistinct or c. 20-30 $\mu \mathrm{m}$ in height; ostiole conspicuous, widely gaping or filled with a glut of conidia; cavity unilocular and lined with the conidiogenous layer; conidiophores made of hyaline, elongate cells; conidiogenous cells elongate or more typically slightly ampulliform, $3-7(-8) \times 1.5-3.5 \mu \mathrm{m}$. Conidia acrogenous, unicellular, typically obpyriform, 
or rarely ellipsoid or biclavate, $(2 \cdot 5-) 3-3 \cdot 5$ $(-4) \times(0 \cdot 7-) 1-1.5 \mu \mathrm{m}$.

Observations. This species has been known to us for more than ten years and has been filed or even mentioned in several publications (Diederich 1989; Scheidegger et al. 1991; Diederich \& Sérusiaux 2000) as a species of Fellhanera. Lack of ascomata of course precludes any final decision on its generic position. Now that we have studied collections from many countries in Europe and failed to find any published epithet for it, we have decided to publish it as new in the genus Fellhanera. Indeed, its pycnidia produce obpyriform conidia that are typical for many species of that genus, for example the so-called $F$. subternella group (Lücking 1997). Production of gyrophoric acid in the pycnidial walls is, however, somewhat divergent as the secondary metabolites so far detected in the $F$. subternella group include only zeorin, usnic and isousnic acids (Lücking et al. 1994), and no depsides nor depsidones; the recently described $F$. viridisorediata, however, is known to produce roccellic acid (Aptroot et al. 1998). The pycnidia of Fellhanera gyrophorica are sessile or shortly stalked; such a characteristic is so far unknown in the Pilocarpaceae except for the recently described and neotropical $F$. pilomarginata Lücking (Lücking 1997) whose conidiogenous layer is rather wideexposed, making the conidiomata much closer in appearance to sporodochia than to genuine pycnidia.

Similar conidia are also known in the related Byssoloma, also a member of the Pilocarpaceae, and the placement of this new species in that genus could be contemplated. There is however no decisive argument for such a decision, and we have thus decided to maintain the first choice made more than ten years ago.

Remarkably similar in appearance to $F$. gyrophorica is Micarea pycnidiophora Coppins \& P. James, which also has $\mathrm{C}+$ red pycnidia (gyrophoric acid). However, the latter has longer, bacilliform conidia, 3.8-6 $\times 1-1 \cdot 2$ $(-1 \cdot 5) \mu \mathrm{m}$, a photobiont with smaller cells
(4-7 $\mu \mathrm{m}$ diam.), and a more oceanic distribution. The related $M$. stipitata Coppins \& $\mathrm{P}$. James has $\mathrm{C}-$ pycnidia that are borne on often branched stalks, even larger conidia, $6-8 \times 1-1.8 \mu \mathrm{m}$, and an even stronger oceanic distribution.

Several other European corticolous species frequently occur without ascomata, but with conspicuous pycnidia. Such species that might be confused with $F$. gyrophorica are listed below [none of these has pycnidia producing gyrophoric acid, and all species, except for Fellhanera ochracea and Fellhaneropsis vezdae, do not belong to the genera to which they are currently assigned and should eventually be moved elsewhere]:

Bacidia carneoglauca (Nyl.) A.L. Sm.pycnidia white-pubescent, larger, $0 \cdot 2-$ $0.4 \mathrm{~mm}$ diam.; conidia oblong, c. $4-6 \times$ $1.5 \mu \mathrm{m}$, and typically with a median constriction; thallus UV+ pink (xanthones); usually on rocks.

Bacidia viridifarinosa Coppins \& Jameslike $B$. cameoglauca but pycnidia smaller, $0.15-0.26 \mathrm{~mm}$ diam., and thallus farinose sorediate; often on bark but also on rocks.

Bacidia trachona (Ach.) Lettau-pycnidia dark grey to bluish black, with walls that react $\mathrm{K}+$ purple; conidia bacillar, 3-5 $\times$ 1-1.5 $\mu \mathrm{m}$; thallus PD+ red (argopsin); usually on rocks.

Catillaria albida Coppins \& Vězda-pycnidia white but typically pruinose and shortly stipitate; conidia bacillar or ellipsoid, $2 \cdot 8-$ $3 \cdot 5(-3 \cdot 8) \times 0 \cdot 8-1 \cdot 2 \mu \mathrm{m}$.

Fellhanera ochracea Sparrius \& Aptrootpycnidia typically orange-brown and conidia also obpyriform but slightly longer (4$6 \mu \mathrm{m})$.

Fellhaneropsis vezdae (Coppins \& P. James) Sérus. \& Coppins--pycnidia pinkish brown, with filiform conidia $(20-) 30-43 \times 0.5-$ $1 \mu \mathrm{m}$; thallus generally thinner and smoother.

Lecidea doliiformis Coppins \& P. Jamespycnidia grey-brown to dark grey, with walls containing a brownish pigment reacting $\mathrm{K}-, \mathrm{N}+$ reddish brown, and an additional green pigment near the ostiole reacting $\mathrm{K}+$ intensifying and $\mathrm{N}+$ red; conidia oblong, $3 \cdot 5-5 \times 1 \cdot 5-2 \mu \mathrm{m}$. 
Distribution and ecology. Fellhanera gyrophorica has been found in Austria, Lithuania, Luxembourg, Poland, Switzerland and Ukraine, and thus appears to be a Central European species. So far it has not been found in the Western parts of Europe and is, for example, unknown in well-explored areas such as Scandinavia, Great Britain and the Pyrenees (France and Spain). It seems to be typical of well-preserved, rather shady and humid, broad-leaved forests at low elevations.

In the type locality, Fellhanera gyrophorica has been collected on several phorophytes, both deciduous (Alnus, Fagus and Quercus) and coniferous (Picea) trees, and associated species found with the specimens available include Anisomeridium polypori, Graphis scripta, Lepraria lobificans, Loxospora elatina, Micarea prasina and Opegrapha vulgata. In Luxembourg, the species is found close to Arthonia vinosa and Lepraria lobificans, and both localities where it has been found are considered to be forests with a long historical continuity (Diederich 1991). According to the detailed notes provided by A. Zalewska for the Polish locality, the Borecka Forest is an almost pristine forest, and associated species of $F$. gyrophorica are Micarea prasina and Opegrapha vulgata. In Switzerland most localities are in lowland, mixed deciduous forests with indigenous Abies alba. In these habitats $F$. gyrophorica is confined to stands with a rich epiphytic lichen flora (e.g. Menegazzia terebrata, Fellhanera bouteillei, $F$. ochracea, F. subtilis, $F$. viridisorediata, Fellhaneropsis vezdae, Graphis elegans, Micarea adnata and Thelotrema lepadinum), which indicates their high ecological continuity. Because of the strong bryophyte competition in the microhabitat occupied by $F$. gyrophorica, often very few accompanying lichen species are found with it. In the Ukrainian Carpathians $F$. gyrophorica has been found on young (c. 40 years old) Carpinus betulus with ubiquitous epiphytic bryophytes, liverworts and lichen species (e.g. Frullania dilatata, Hypnum cupressiforme, Graphis scripta, Lepraria lobificans, Melanelia glabratula, Phlyctis argena and Pyrenula nitida).
Specimens examined. Austria: Oberösterreich: Almtal, Almbrücke hinter Tierpark, alt. $570 \mathrm{~m}$, on Picea abies, 1997, F. Berger 11261 (hb Berger). Steiermark: Oststeirisches Hügelland, Bezirk Feldbach, $2 \mathrm{~km} \mathrm{NW}$ von Feldbach, Kornberger Teiche, auf Borke von Quercus robur, Picea abies und Fagus sylvatica, 1993, B. Wieser 1688 (checked by TLC), 1689, 1692 (checked by TLC) \& 1988 (GZU).--Lithuania: Trakai distr.: Varniku forest, on trunk of Quercus robur in old pine-oak forest, 1998, 9. Motiejunaite 3150 (BILAS, LG; checked by TLC); Viesvile strict nature reserve, quarter no. 60 , area 9, on trunk of Alnus glutinosa in old alder-ash forest, 1998, f. Motiejunaite 3707 (BILAS).Luxembourg: Gutland: NEE Haller, Halerbaach, sur Quercus, 1986, P. Diederich 7595 (hb Diederich); SE Beaufort, Haupeschbaach, sur Quercus, 1986, P. Diederich 7616 (hb Diederich).-Poland: Suwvatki distr.: Borecka Forest (sg. 50), 'Lipowy Jar' reserve, old Carpinus-Quercus-Tilia (Tilio-Carpinetum), 1996, A. Zalewska 1356 (OLS; checked by TLC).Switzerland: Aargau: Vordemwald, on Fagus in a mixed forest with Abies alba. Quercus sp. and Fagus sylvatica, one thallus found in ix 1990, gone in 1997 because of bryophyte competition, C. Scheidegger (hb Scheidegger). Bern: Därligen, on Abies alba in an oldgrowth Abies-Fagus forest along a gorge, 15 v 1999, C. Scheidegger (hb Scheidegger); Commune of Neuenegg, on Fagus sylvatica in a humid mixed forest, $30 \mathrm{v} 1997$, C. Scheidegger (hb Scheidegger) [the population has been damaged by the storm 'Lothar' on 26th December 1999]; Wachseldorn, on Abies alba in an Abies forest, 1996, M. Frei (G); Teufenthal, on Abies alba in a mixed Picea abies forest, 1998, I. Roth \& M. Frei (G).Ukraine: Zakarpatska oblast: Velyky Berezny distr.: Kostrino forestry, Nimetzky ['German'] stream, alt. C. $350 \mathrm{~m}$, on trunk of large Abies by side stream, 1988, B. Coppins et al. 19274 (E, hb Scheidegger; checked by TLC); near village of Zhornava, Parashynsky stream, 370-400 m, on Carpinus, 1998, B. Coppins et al. 19275 ( $E$, hb Scheidegger; checked by TLC).

We thank F. Berger, J. Motiejunaite, B. Wieser, and A. Zalewska for the loan of the material they had collected and for allowing us to include their reports in the present description of the species, and the following institutions for easy access to material in their care: BILAS, GZU and OLS. We also thank Prof. J. Lambinon for checking our manuscript and for making several interesting suggestions. C. Scheidegger thanks the Swiss Agency for the Environment, Forest and Landscape for a research grant (Red-list of epiphytic species)

\section{REFERENCES}

Aptroot, A., Brand, M. \& Spier, L. (1998) Fellhanera viridisorediata, a new sorediate species from sheltered trees and shrubs in Western Europe. Lichenologist 30: 21-26.

Diederich, P. (1989) Les lichens épiphytiques et leurs champignons lichénicoles (macrolichens exceptés) du Luxembourg. Travaux Scientifiques du Musée national d'histoire naturelle de Luxembourg 14. 
Diederich, P. (1991) Les forêts luxembourgeoises à longue continuité historique. Bulletin de la Société des Naturalistes luxembourgeois 92: 31-39.

Diederich, P. \& Sérusiaux, E. (2000) The Lichens and Lichenicolous Fungi of Belgium and Luxembourg. An Annotated Checklist. Luxembourg: Musée national d'histoire naturelle.

Ekman, S. \& Arup, U. (2000) Notes on the lichen flora of southern Sweden III. Graphis Scripta 11: 41-47.

Kalb, K., Lücking, R. \& Sérusiaux, E. (2000) Studies in Bacidia sensu lato (Lichenized ascomycetes: Lecanorales) I. The genus Bapalmuia. Mycotaxon 75: 281-309.

Lücking, R. (1997) Additions and corrections to the knowledge of the foliicolous lichen flora of Costa Rica. The genus Fellhanera, with notes on Bacidia pauciseptata. Tropical Bryology 13: 141-173.

Lücking, R, Lumbsch, H. T. \& Elix, J. A. (1994) Chemistry, anatomy and morphology of foliicolous species of Fellhanera and Badimia (Lichenized Ascomycotina: Lecanorales). Botanica Acta 107: 393-401.

Lücking, R., Cáceres, M. E. da S., Kalb, K. \& Sérusiaux, E. (2001) Studies in Bacidia sensu lato (lichenized Ascomycetes: Lecanorales) II. Six new combinations in Fellhanera Vèzda. Lichenologist 33: 189-194.

Orange, A. (1999) Fellhanera viridisorediata. In New, rare and interesting British lichen and lichenicolous fungus records (C. J. B. Hitch, ed.) British Lichen Society Bulletin 84: 49.

Puntillo, D., Bricaud, O. \& Sérusiaux, E. (2000) A further locality with foliicolous lichens in Italy, with taxonomical and ecological data on foliicolous lichens in Western Europe. Cryptogamie: Mycologie 21: $171-186$

Scheidegger, C., Dietrich, M., Frei, M., Keller, C., Kuhn, N. \& Wildi, E. (1991) Zur Waldflechtenflora des westlichen Aargauer Mittellandes und ihrem Wandel seit 1960. Mitteilungen der Aargauischen Naturforschenden Gesellschaft 33: 175-192.

Sérusiaux, E. (1996) Foliicolous lichens from Madeira, with the description of a new genus and two new species and a world-wide key of foliicolous Fellhanera. Lichenologist 28: 197-227.

Sparrius, L. \& Aptroot, A. (2000) Fellhanera ochracea, a new corticolous lichen species from sheltered habitats in Western Europe. Lichenologist 32: 515-520.

Spier, L. \& Aptroot, A. (2000) Fellhaneretum myrtillicolae ass. nov., the lichen association on Vaccinium myrtillus. Herzogia 14: 43-47.

Vězda, A. (1986) Neue Gattungen der Familie Lecideaceae s. lat. (Lichenes). Folia Geobotanica et Phytotaxonomica, Praha 21: 199-219. 
Downloaded from https://www.cambridge.org/core. Library of Eawag, Empa, PSI \& WSL, on 07 Jun 2018 at 10:32:02, subject to the Cambridge Core terms of use, available at https://www.cambridge.org/core/terms. https://doi.org/10.1006/lich.2001.0328 